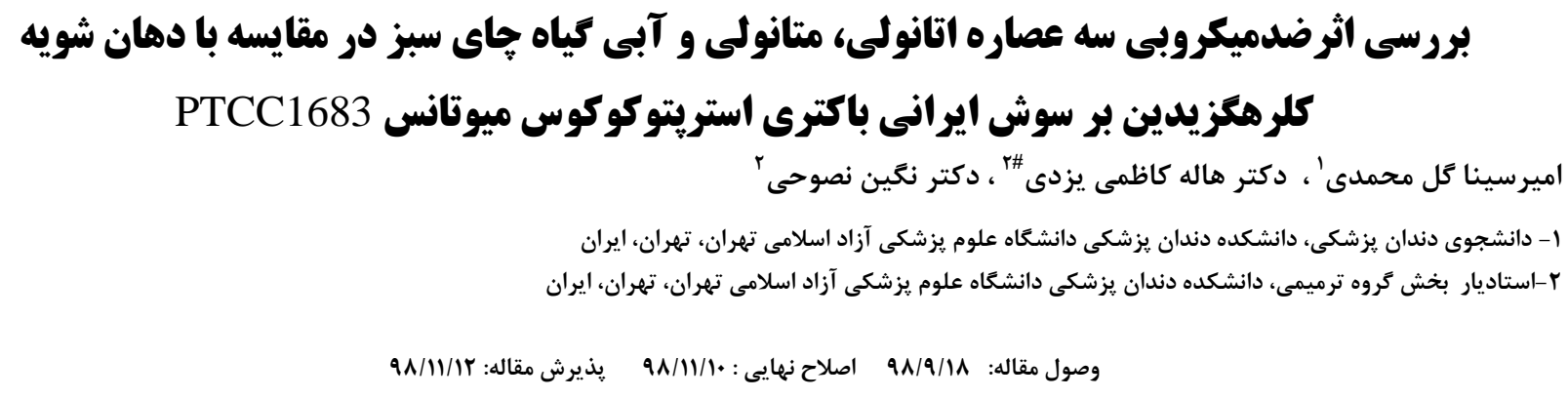

\title{
The study on antimicrobial effect of three ethanolic, methanolic and aqueous extracts of green tea in comparison to chlorhexidine mouthwash on Iranian strain of bacteria Streptococcus mutans PTCC 1683
}

\author{
AmirSina Golmohammadi' ${ }^{1}$ Haleh Kazemi Yazdi*2, Negin Nasoohi ${ }^{2}$ \\ IPh.D. Student of Dentistry, Faculty of Dentistry, Tehran Medical Sciences, Islamic Azad University, Tehran, Iran \\ ${ }^{2}$ Assistant professor, Restorative Dentistry Dept, Faculty of Dentistry, Tehran Medical Sciences, Islamic Azad University, \\ Tehran, Iran
}

\section{Abstract}

Received:Dec 2019

; Accepted: Jan 2020

Background and aim: Dental caries is a major health problem nowadays. polyphenolic compounds of tea can exert its anti-cariogenic effects by affecting the cariogenic Streptococcus Mutans bacteria. The aim of this study was to investigate the antimicrobial effect of ethanolic, methanolic and aqueous extracts of green tea in comparison with chlorhexidine on Iranian strain of this bacteria.

Materials and Methods: $10 \mathrm{~g}$ of green tea powder was dissolved in $100 \mathrm{mg}$ of ethanol, methanol and aqueous solvents separately. After one week, the obtained solutions were filtered and $100 \mathrm{mg} / \mathrm{ml}$ solution was extracted. to evaluate the diameter of inhibition, zone The Swabs impregnated with suspension scrubbed on culture medium. the extracts were injected onto special paper discs and the impregnated disks were placed on the bacterial culture media, plates were kept in the incubator for 24 hours at $37^{\circ} \mathrm{C}$ and then the diameter of inhibition zones was calculated. Using Muller Hinton Broth, herbal extracts were made at concentrations $1: 2(50 \mathrm{mg} / \mathrm{ml})$ and $1: 4(25 \mathrm{mg} / \mathrm{ml})$ and $1: 8(12.5 \mathrm{mg} / \mathrm{ml})$ and $1: 16(6.25 \mathrm{mg} / \mathrm{ml})$ and $1: 32(3.125 \mathrm{mg} / \mathrm{ml})$. Then, $100 \mu 1$ microbial suspensions made by standard McFarland 0.5 were transferred to all test tube. The test tubes were placed in an incubator at $37^{\circ} \mathrm{C}$ for 24 hours. After 1 day, contents of all test tubes were separately cultured on Muller Hinton Broth medium. The culture media were incubated at $37^{\circ} \mathrm{C}$ for 1 day. The results were evaluated in the form of growth or non-growth of bacterial colonies on culture media and MBC and MIC were determined. ANOVA and Post hoc test was used for statistical analyze with SPSS Software.

Results: Experimental results after three iterations showed mean values of 16.16, 16.66, 12.5 and $17.5 \mathrm{~mm}$ for diameter of the inhibition zone of ethanolic, methanolic and aqueous extracts and chlorhexidine $0.2 \%$, as control. Also, at the significant level of 0.05 , there was no significant difference between the diameter of the inhibition zone of ethanol, methanol and chlorhexidine extracts. ( $>0.05$ )The Aqueous Extract Showed Significant difference with other Extracts. MBC Reported $12.5 \mathrm{mg} / \mathrm{ml}$ for Ethanolic and $50 \mathrm{mg} / \mathrm{ml}$ for two other extracts. MIC Reported $6.25 \mathrm{mg} / \mathrm{ml}$ for ethanolic and $25 \mathrm{mg} / \mathrm{ml}$ for two other extracts.

Conclusion: The results showed that the antimicrobial effects of ethanolic and methanolic extract of Iranian green tea are higher than aqueous extract and there is no significant difference between these two extracts with Chlorohexidine.

Keywords: green tea, Streptococcus Mutans, zone of inhibition, MIC, MBC

*Corresponding Author: HMSCRES.ky@gmail.com

J Res Dent Sci. 2020; 17(1): 17-24 


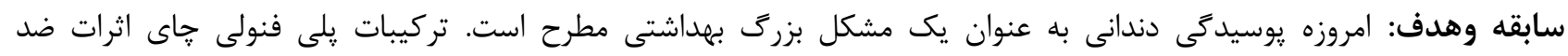

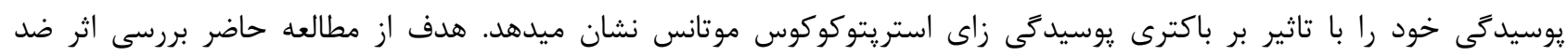

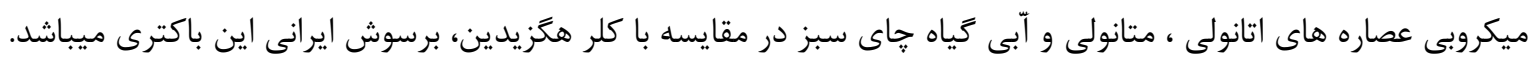

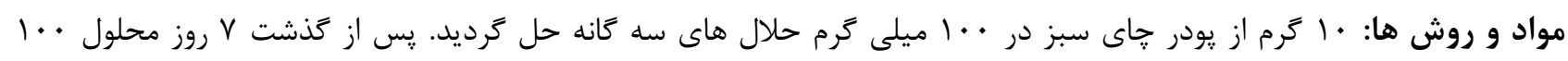

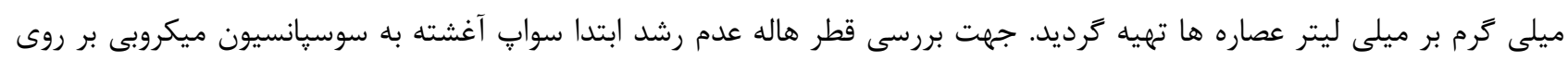

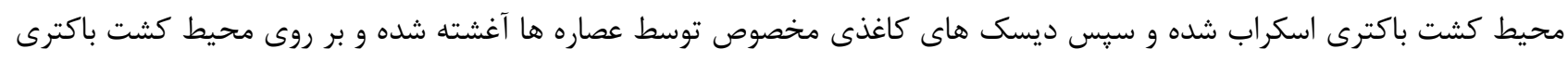

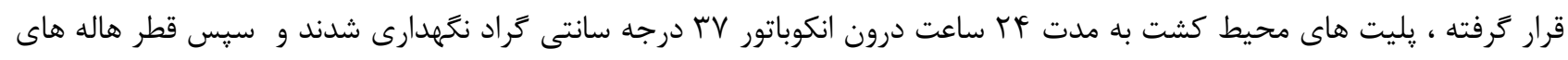

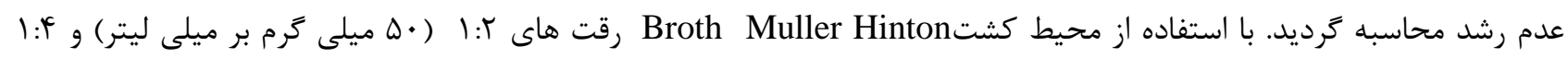

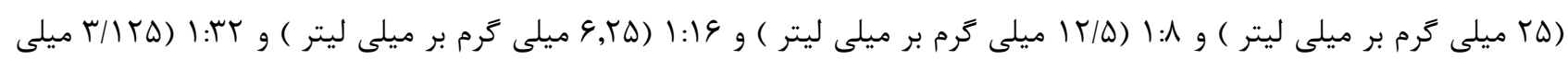

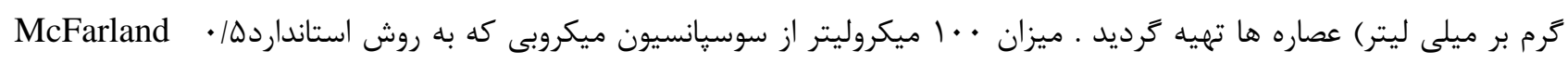

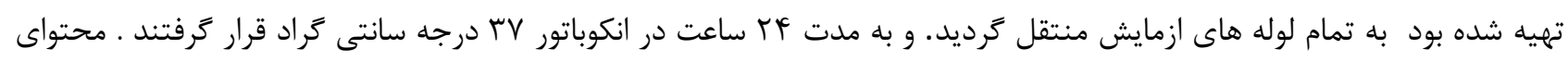

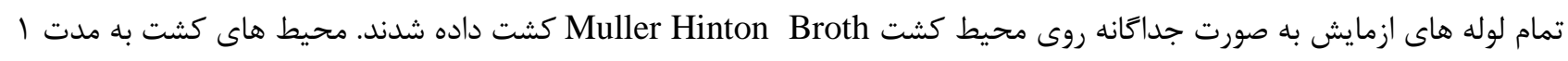

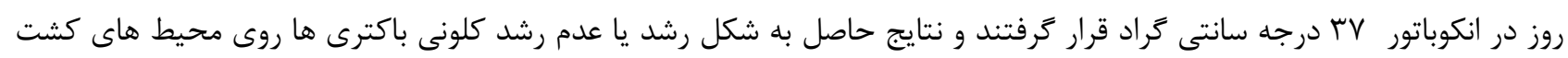

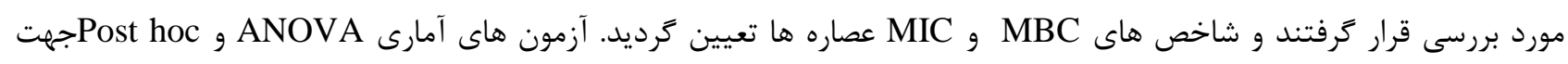

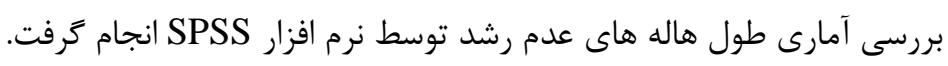

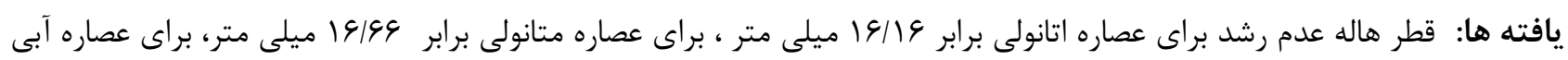

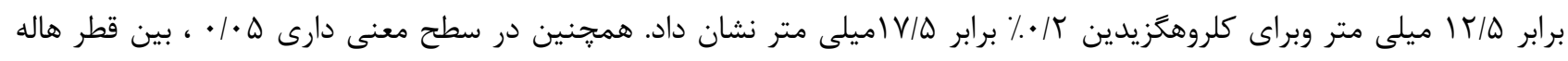

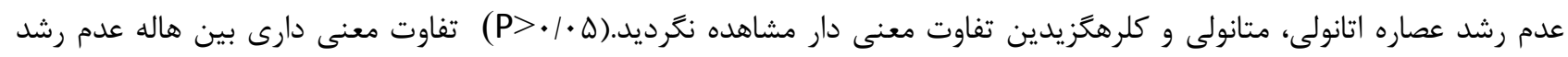

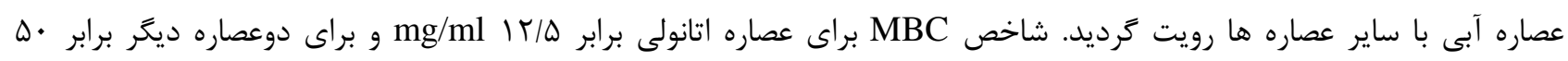

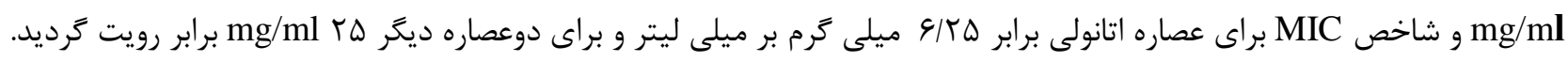

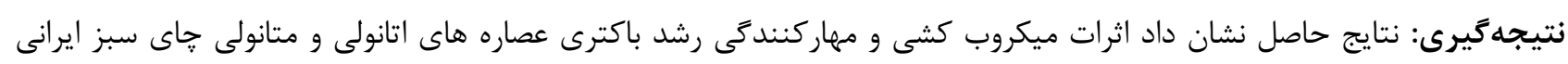

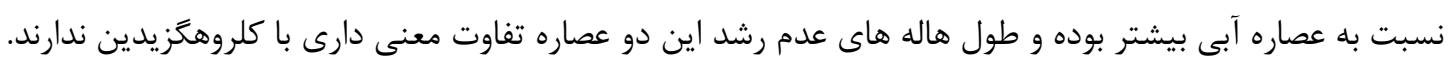

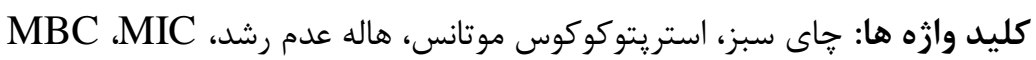

مقدمه:

يوسيدگى دندانى به عنوان يك مشكل بهداشتى مى تواند در

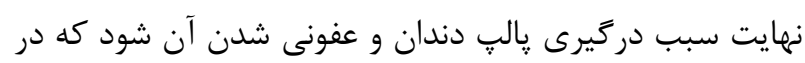
صورت عدم درمان به موقع حتى ممكن است دندان مبتلا نياز

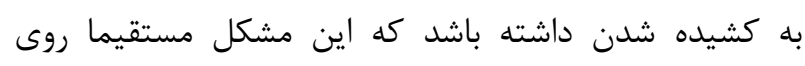

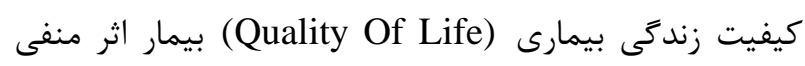
خواهد داشت. (r) مطالعات در ايران بيانكر سطوح بالاى شاخص DMFT هستند.

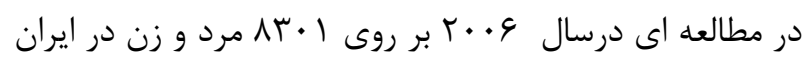

يوسيدكى دندانى امروزه به عنوان يكى از بزركترين و مههم ترين معند

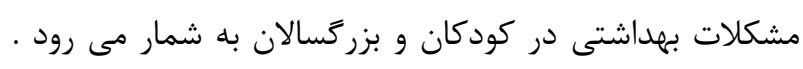

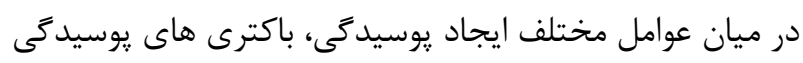

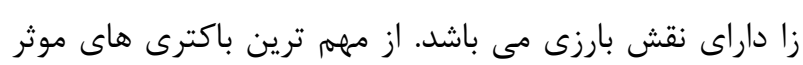

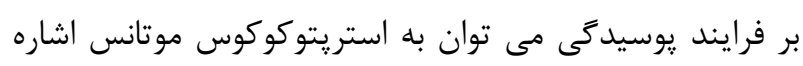

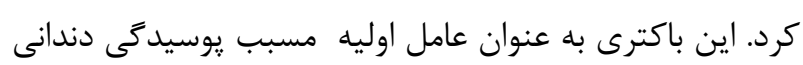
شناخته مى شود. (1) 
محققان اثرات خاى سبز به شكل آزمايشًاهى و كلينيكى را به انجام رسانده اند و از حلال هاى مختلف و در غلظت هاى متفاوت بر سوش هاى مختلف باكترى استريتوكوكوس موتانس

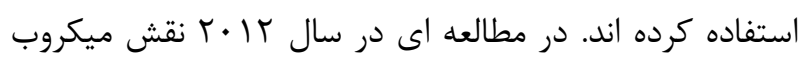

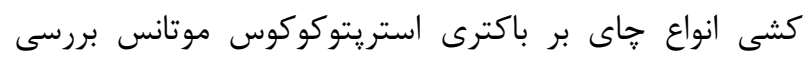

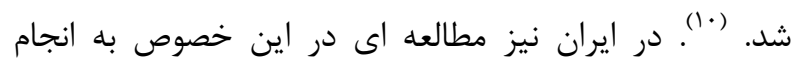
رسيده است. نادرى و همكاران در سال || • ب نقش جاى سبز و سياه را بر روى باكترى استريتوكوكوس موتانس نشان

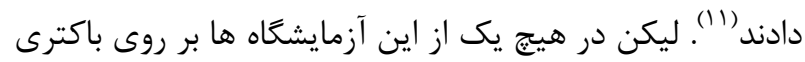
بومى ايران كه به صورت فلور ميكروبى در دهان جامعه ايرانى موجود بوده و با ساير جوامع متفاوت بوده بررسى صورت نكرفته دئه

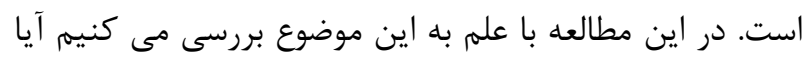

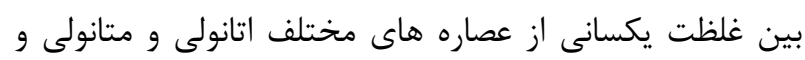
آبى خاى سبز تفاوت بر روى ميزان خاصيت ضد ميكروبى عليه تايڤ بومى باكترى استريتوكوكوس موتانس در مقايسه با شاهد كلرهكَيدينى وجود دارد يا خير. در نهايت نيز بررسى مى كنيم

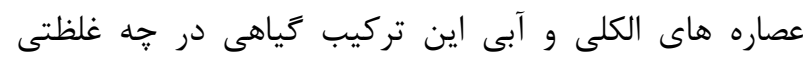
حداقل خاصيت ميكروب كشى (MBC) و و حداقل خاصيت مهار كنندگى باكترى (MIC) خود را القا ميكنند.

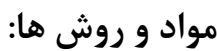

اين مطالعه يك مطالعه تجربى - آزمايشكاهى با محتواى كاربردى بوده است. به اين منظور برى جاى سبز تازه لاهيجان

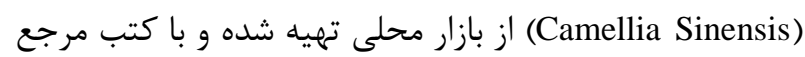

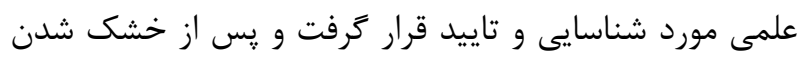
در جاى خنك و تاريك، توسط دستگاه آسياب برقى خرد

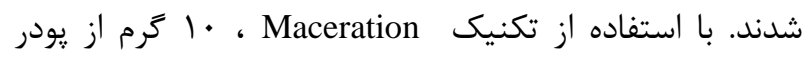

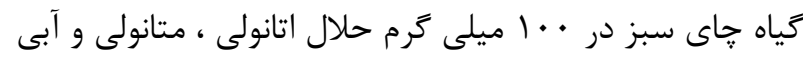

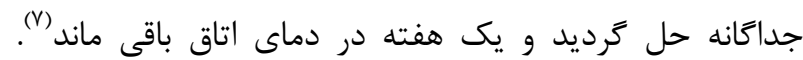
محلول هاى بدست آمده با استفاده از فيلتركاغذى مhatman شماره ا و قيف بوخنر فيلتر شده و در نهايت از يودر حاصل،

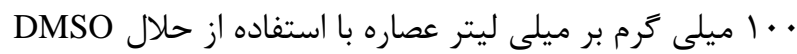

اين افراد به طور ميانگين داراى r/VIY/9 دندان يوسيده بوده اند كه اين امار نيز بيانكر نياز توجه بيشتر به امر بهداشت دهان اندان و دندان و استفاده از روش هاى بيشگيرى از يوسيدگى دندان مى باشد.) باكترى استريتوكوكوس موتانس با تشكيل يك لايه بيوفيلم بر

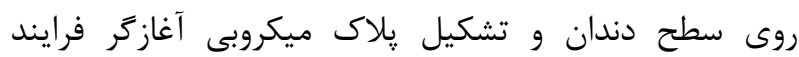

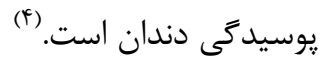
باكترى استريتوكوكوس موتانس با اتصال به سطح ميناى دندان و ترشح ذرات يلى ساكاريدى خارج سلولى با استفاده از كربوهيدرات هاى قابل تخمير مانند ساكارز طى فرايند حليكوزيل ترانسفراز باعث اتصال به سطح ميناى دندان و توليد اسيد مى شود، كه در نهايت منجر به انحلال سطح ميناى

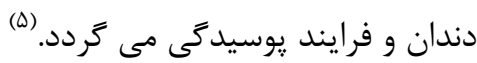
با توجه به نقش بارز اين باكترى تلاش براى كاهش سط سطح برد آن

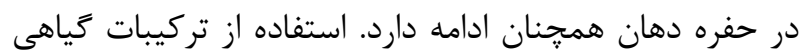
به اين منظور در تحقيقات مختلف مورد نظر بوده است و جاى

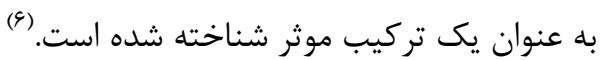
استفاده از كياهان دارويى از كذشته هاى دور براى درمان انواع بيمارى ها مورد نظر بوده است و از اين ميان بيمارى هاى

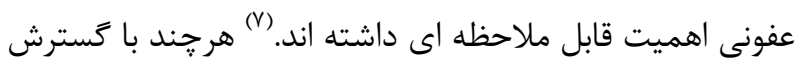
شاخه هاى مختلف علوم مانند داروهاى فيتوشيمى و و

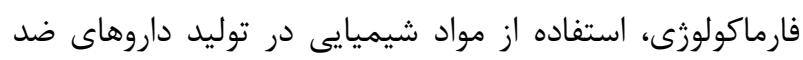
باكتريايى توجه محققين را به خود معطوف كرد، اما به دليل

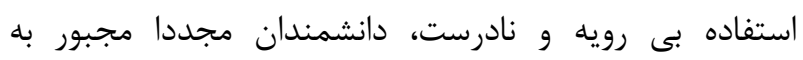
استفاده از تركيبات كياهى در درمان بيمار هاى عفونى شده اند

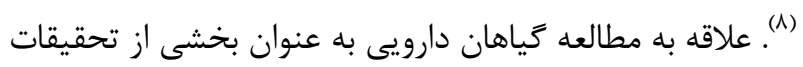
فارماكولوزى در سراسر جهان در حال افزايش است. توان عصاره هاى گياهى در متوقف و مهار كردن رشد استريتوكوكوس موتانس مورد بررسى قرار كرفته است. اين موضوع مى تواند

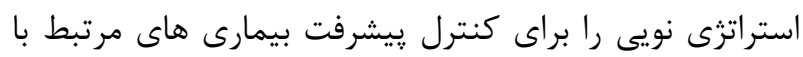

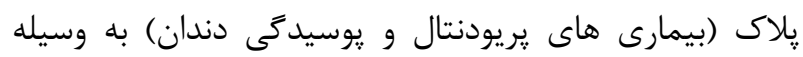

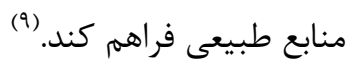




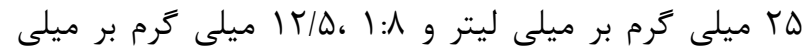

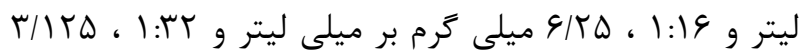
ميلى گرم بر ميلى ليتر عصاره هاى اتانولى ، متانولى و آبى گياه

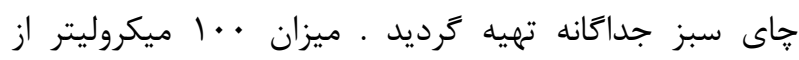

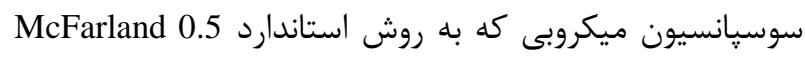

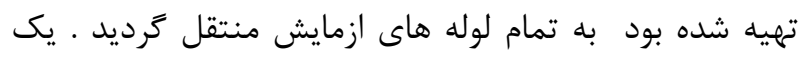

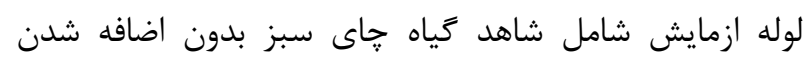

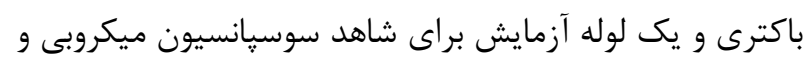

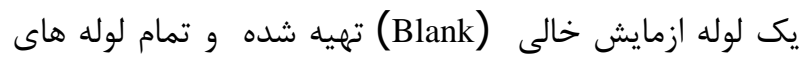
ازمايش به مدت FF ساعت در انكوباتور YrV درجه سانتى گراد

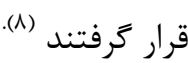
بعد از ب Tاعت محتواى تمام لوله هاى ازمايش به صورت جداعانه روى محيط كشت Muller Hinton Broth كشت لماع داده شدند. محيط هاى كشت به مدت ا روز در انكوباتور مV دو درجه

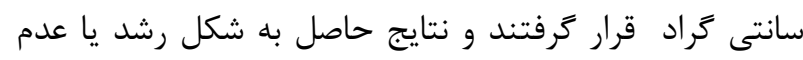
رشد كلونى باكترى ها روى محيط هاى كشت مورد بررسى قرار كرفتند و شاخص MIC براى تمام عصاره هاى اتانولى متانولى و

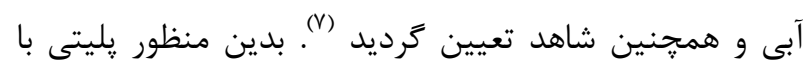
حداقل رقت كه فاقد هر كونه ميكروار كانيسم بوده و هيج رشد باكترى در آن صورت نكَرفته بود به عنوان يليت MBC در نظر

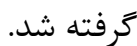

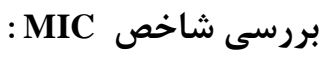

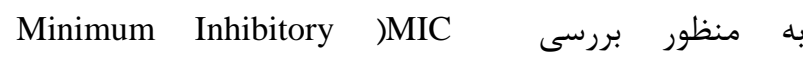
يليتى با حداقل رقت كه فاقد كمترين رشد Concentration باكترى بوده و رشد باكترى در آن متوقف شده بود به عنوان يليت MIC د بر نظر كرفته شد.

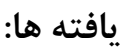

در اين تحقيق با هدف بررسى هاله عدم رشد ناشى از عصاره هاى جاى سبز بر سوش ايرانى باكترى استريتوكوكوس

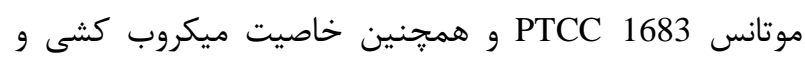
مهاركنندگى رشد باكترى، قطر هاله هاى عدم رشد ناشى از همان
UV دى متيل سولفواكايد) تهيه كرديد و تحت اشعه (I)

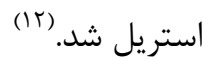
بررسى قطر هاله عدم رشد ناشى از عصاره هاى اتانولى متانولى و آبى تياه جاى سبز: جهت بررسى قطر هاله عدم رشد از محيط كشت مولر هينتون

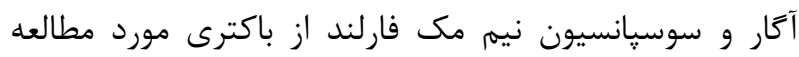
استفاده كرديد. سوسيانسيون باكتريايى نيم مك فارلند در سرم

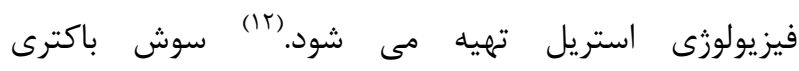
استريتوكوكوس موتانس 1683 PTCC از مركز كلكسيون

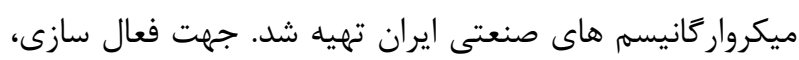

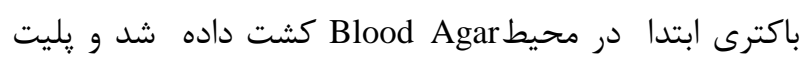

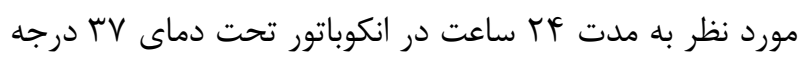

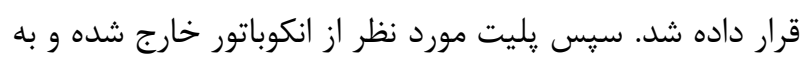
وسيله آن سوسيانسيون نيم مك فارلند در زير هود تهيه

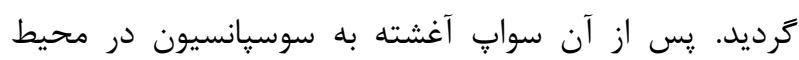
استريل و در زير هود آزمايشخاه بر روى محيط كشت اسكراب كرديد. سيس عصاره هاى به دست آمده و و همجنين

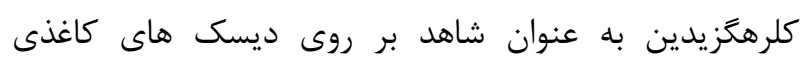

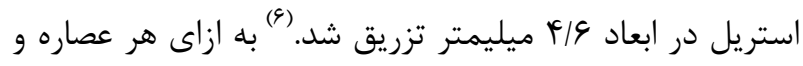

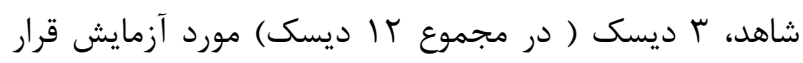

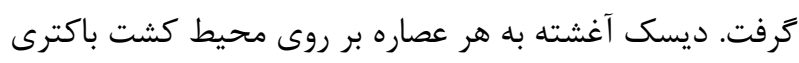
كذاشته شد. در زير هر ديسك، عددى به عنوان كد نمونه

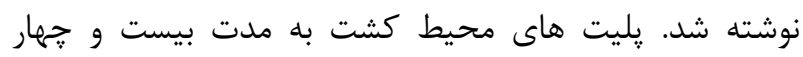

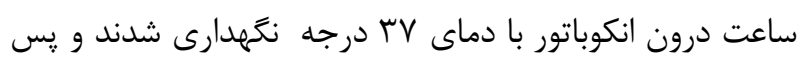

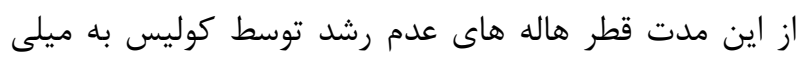

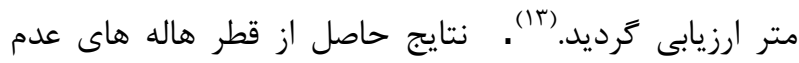

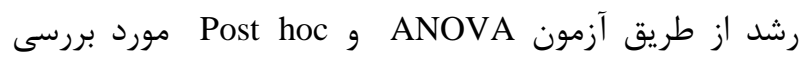
آمارى قرار كرفت. بررسى شاخص MBC: Minimum Bactericidal ) MBC كر مرحله بعد شاخص سرحسى Broth Muller با استفاده از محيط كشت Concentration Hinton 
آناليز آمارى نشان داد تفاوت طول هاله هاى عدم رشد ناشى

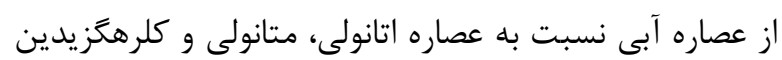

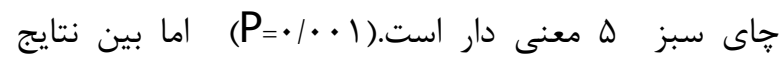

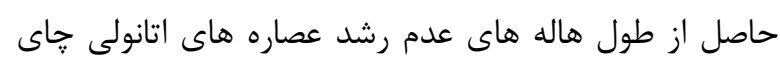

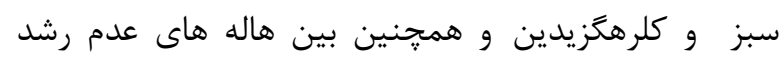

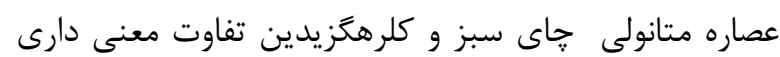

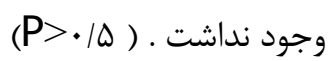

همجنين بين نتايج حاصل از هاله عدم رشد عصاره اتانولى و متانولى نيز تفاوت معنى دارى مشاهده نشد.

بحث:

اين تحقيق با هدف بررسى هاله عدم رشد ناشى از عصاره

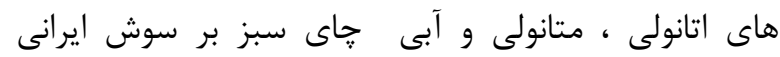
باكترى استريتوكوكوس موتانس 1683 PTCC و همجنين خاصيت ميكروب كشى و مهاركنندگى رشد باكترى، قطره

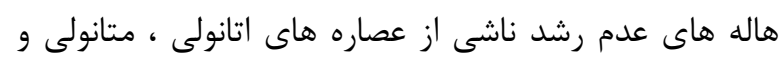

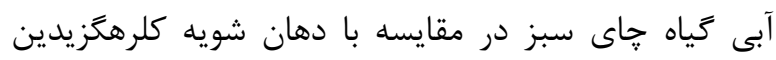

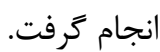
بررسى هاى آمارى نشان داد تفاوت طول هاله هاى عدم رشد

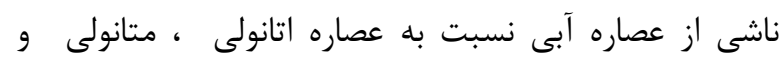
كلرهكزيدين معنى دار است. اما بين نتايج حاصل از طول هاله هاى عدم رشد عصاره هاى اتانولى خاى سبز و و كلرهكزيدين و همجنين بين هاله هاى عدم رشد عصاره متانولى جاى سبز و كلرهكزيدين تفاوت معنى دارى وجود

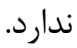
همجنين بين نتايج حاصل از هاله عدم رشد عصاره اتانولى و متانولى نيز تفاوت معنى دارى مشاهده نشد.

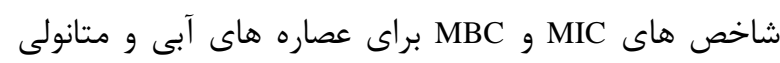
برابر بود و به ترتيب له و •له ميلى گرم بر ميلى ليتر ثبت كرديد در حالى كه اين شاخص ها براى عصاره اتانولى به

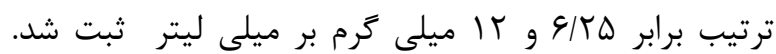

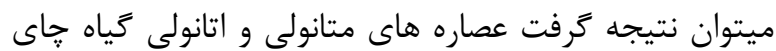

عصاره هاى اتانولى ، متانولى و آبى گياه خاى سبز در مقايسه با دهان شويه كلرهكزيدين محاسبه ترديد و از طريق آزمون Post hoc و به وسيله نرم افزار SPSS ANOVA

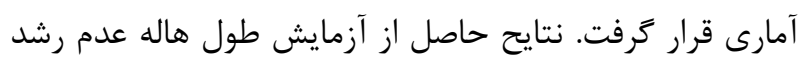

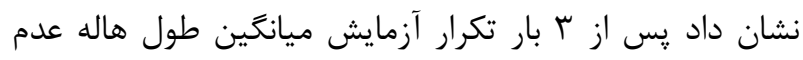

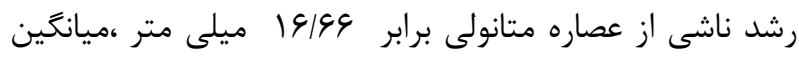

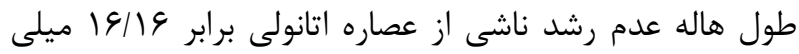
متر ، ميانكين طول هاله عدم رشد ناشى از عصاره آبى برابر

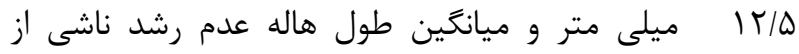

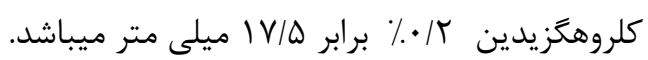
جدول ا- قطر هاله هاى عدم رشد ناشى از عصاره هاى اتانولى ،

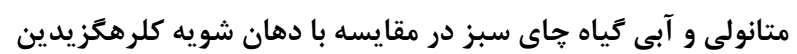
بر حسب ميلى متر

\begin{tabular}{|c|c|c|c|c|}
\hline كلروهكَزيدين & عصاره & متانولى & عصاره & \\
\hline IV & $19 / 0$ & 19 & r & رشول هاله عدم ازمايش \\
\hline 11 & $19 / 0$ & $I V / \Delta$ & IT & رشول هاله عدم ازمايش \\
\hline$I V / \Delta$ & $1 \Delta / \Delta$ & $19 / 0$ & $\mid r / \Delta$ & رش رشد آزمايش هاله عدم \\
\hline$I V / D$ & $19 / 19$ & 19198 & $I T / \Delta$ & ميانگین \\
\hline
\end{tabular}

همجنين يس از آزمايش رقيق سازى ، حداقل غلظت مهار كننده رشد باكترى (MIC) و حداقل غلظت كشنده باكترى مطابق جدول زير حاصل گرديد: (MBC)

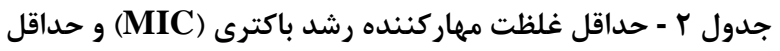

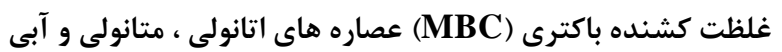
تياه جاى سبز

\begin{tabular}{|c|c|c|}
\hline MBC & MIC & كياه \\
\hline $\mathrm{Mg} / \mathrm{ml}$ & $\mathrm{Mg} / \mathrm{ml}$ & \\
\hline a. & $r \Delta$ & عصاره آبى \\
\hline a. & $r \omega$ & عصاره متانولى \\
\hline $\mid r / \Delta$ & $q / \pi \Delta$ & عصاره اتانولى \\
\hline
\end{tabular}


و شاخص هاى MBC MIC به ترتيب Q 9 و و I ا ميلى

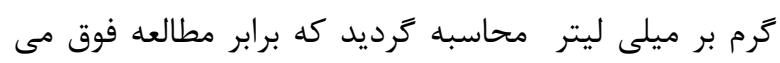

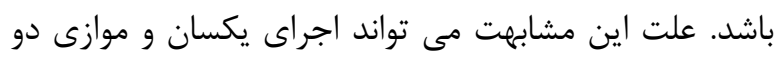

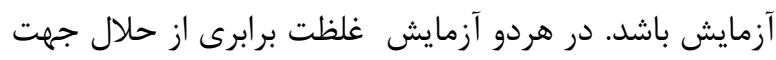

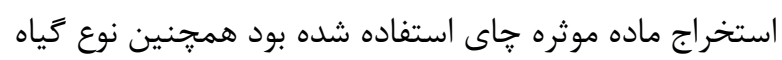

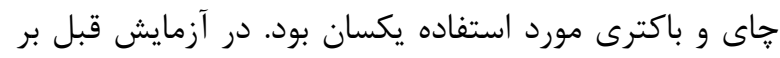

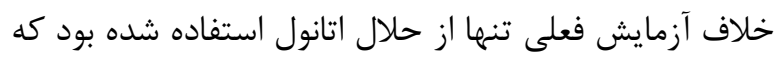
به منظور بررسى اثر حلال هاى مختلف بر خاصيت ميكروب إنى كشى عصاره خاى سبز، اين موضوع براى اين مطالعه مورد برسى قرار كرفت. (IV) در مطالعه اى ديخر در كشور :برتغال بر روى سوش امريكايى

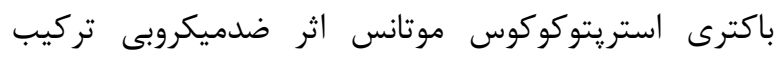
عصاره آبى دو جاى سبز و سياه مورد بررسى قرار كرفت.

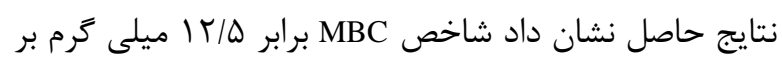
ميلى ليتر بوده است كه با تحقيق فعلى برابرى مى كند. اما ميزان شاخص MIC نيز برخلاف تحقيق فعلى به همين ميزان

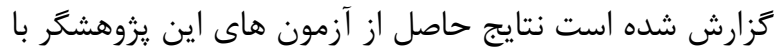
اين نتايح حاصل از آزمايش فعلى متفاوت است كه مى توان علت اين يديده در شرايط آزمايش بررسى كرد. در آزمون اين يزوهشكر يرتغالى از تركيب دو جاى استفاده شده است كه ممكن است نتايج حاصل از آزمايش را تحت تاثير قرار دهد. همجنين سوش باكترى مورد استفاده كاملا متفاوت مى باشد.

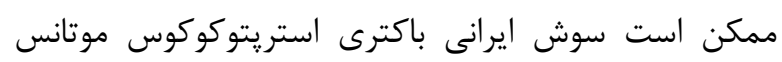
نسبت به سوش ATCC مقاومت متفاوتى بـ 35688 PTC 1683

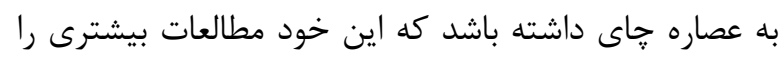

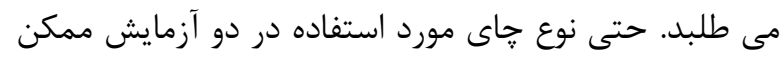
است نتايج آزمايش را تحت تاثير قرار دهد. ممكن است مورد ميزان ماده موثر يلى فنول در انواع مختلف خاى دائ در كشور

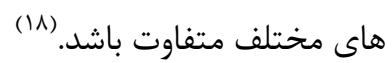

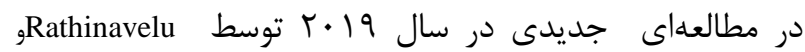
همكاران صورت گرفت عصاره هاى اتانولى و متانولى جاى جاى سبز و جاى سياه استخراج شده و خاصيت ضد ميكروبى آن مورد هرد هاى
سبز تفاوت معنى دارى در ارتشاح ماده موثره به محيط اطراف ديسك از خود نشان ندادند در حالى كه عصاره آبى در

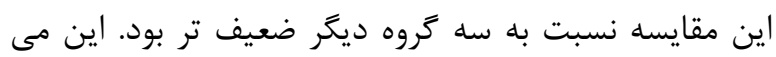

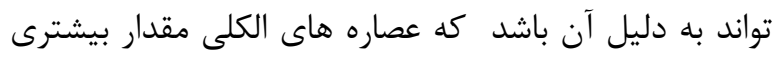

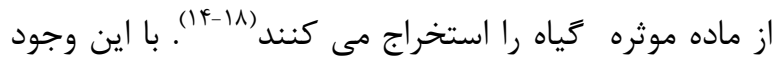

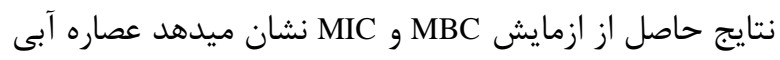
كرجه از توان ارتشاح كمترى در محيط اطراف ديسك إسى

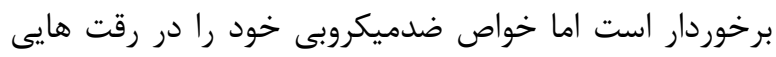

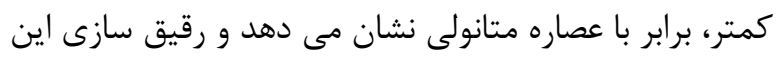

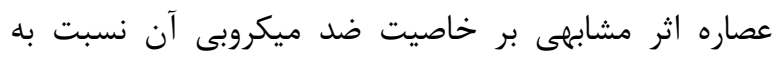
عصاره متانولى دارد. عصاره اتانولى بر خلاف دو عصاره ديخر در آزمون رقيق سازى تا غلظت هاى كمترى خاصيت ضد خدارد ميكروبى خود را حفظ كرد و مى توان نتيجه كرفت نسبت به نائ

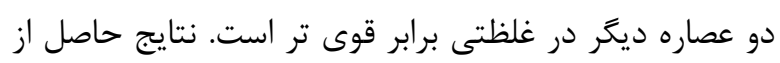

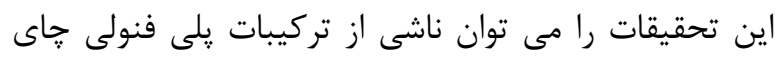

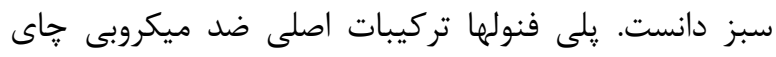

سبز هستند. در اين ميان Epigallocatechinو Epigallocatechin-3-Gallate هاى خاى سبز شناخته ميشود. Epigallocatechin-3-Gallate با اتصال به يֶيتيدو

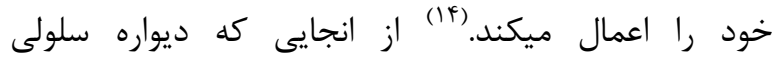

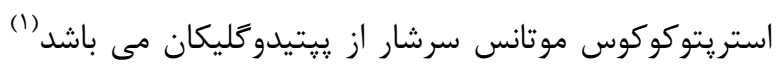
،اثر ضدميكروبى خاى سبز بر اين باكترى به اين شكل قابل

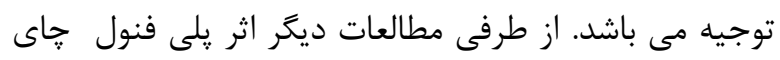

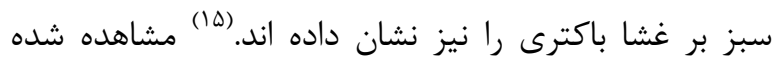

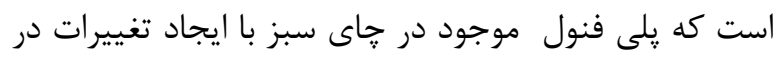

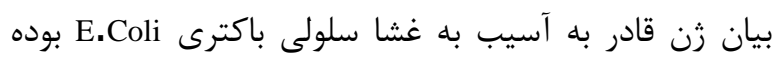
است (If.V)

نتايج اين تحقيقات با تحقيق مشابهى كه در سال 11 إن صورت كرفته است ، هم سو مى باشد. در مقاله مشابه با تلإن مطالعه حاضر قطر هاله عدم رشد ناشى از عصاره اتانولى كياه

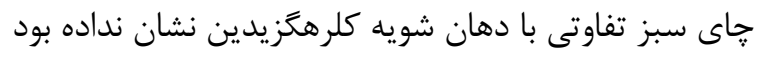




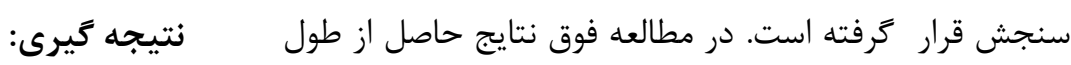

نتايج مطالعه حاضر بيان مى دارد كه عصاره هاى اتانولى و

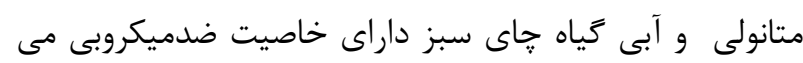
باشند كه اين خاصيت در رقت هاى پايين ترى توسط عصاره

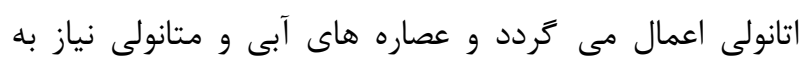
رقت هايى بالاتر جهت اعمال خاصيت ضدميكروبى خود دارند.

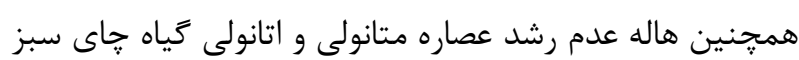
تفاوت قطر معنى دارى نسبت به كلرهكَيدين نداشتند كه اين رين

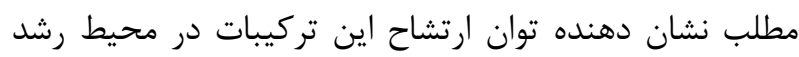

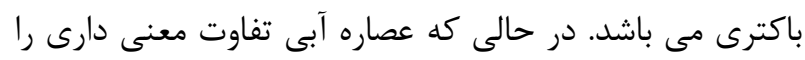

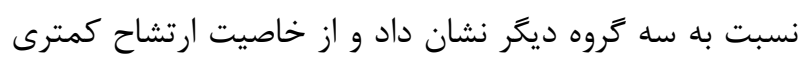
برخوردار بود.

$$
\text { تشكر و قدردانى }
$$

نكارندگان مراتب تشكر و قدردانى خود را از شركت وارنا يايا يزوه مهام به سبب همكارى هاى صورت كرفته ابرازميدارند. هاله عدم رشد كلرهكزيدين نسبت به تركيبات ديخر بيشتر بود درد

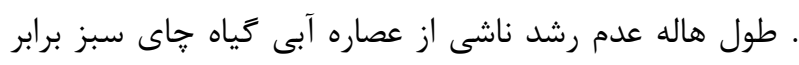

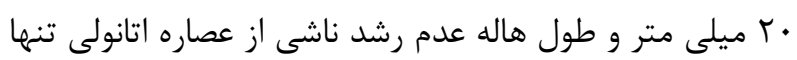
צ ميلى متر ززارش ترديد. نكته قابل توجه در اين مقاله عصاره

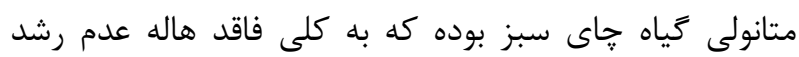
بوده و مقدار آن صفر ميلى متر ززارش شده است كه در تضاد

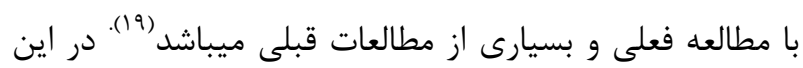
يزوهش تست هاى MBC و MIC جهت بررسى قدرت عصاره ميكروبى صورت نكرفته است . معرفى دقيقى از باكترى مورد

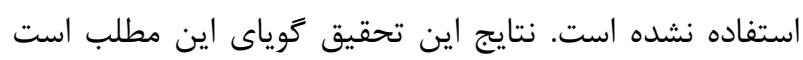

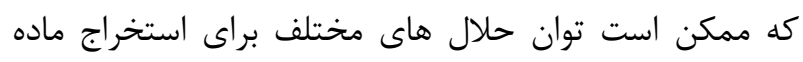

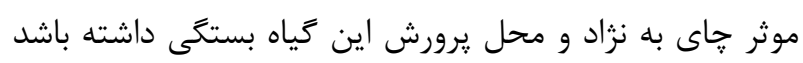

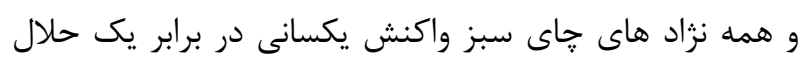
مشخص نداشته باشند كه اين خود نيازمند مطالعات بيشتر است. 


\section{References:}

1.Hamada S, Slade HD. Biology, immunology, and cariogenicity of Streptococcus mutans. Microbiological reviews .1980;44(2):331

2.Saintrain MV, de Souza EH. Impact of tooth loss on the quality of life.Gerodontology. 2012;29(2): 632-6. 3.Hessari H, Vehkalahti MM, Eghbal MJ, Murtomaa HT. Oral health among 35-to 44-year-old Iranians. Medical Principles and Practice. 2007;16(4):280-5. [Persian]

4.Krzyściak W, Jurczak A, Kościelniak D, Bystrowska B, Skalniak A.The virulence of Streptococcus mutans and the ability to form biofilms. European Journal of Clinical Microbiology \& Infectious Diseases. 2014;33(4):499-515.

5.Ashrafi B, Ramak P, Ezatpour B, Talei GR. Investigation on chemical composition, antimicrobial, antioxidant, and cytotoxic properties of essential oil from DracocephalumkotschyiBoiss. African Journal of Traditional, Complementary and Alternative Medicines. 2017;14(3):209-17.

6.Haghighati F, Jafari S, BEYT EJ. Comparison of antimicrobial effects of ten Herbal extracts with chlorhexidine on three different oral pathogens; an in vitro study. Hakim Research Journal.2003 ;6(3):71-7. [Persian]

7.Ahmadi E, Abdollahi A, Najafipour S, Meshkibaf MH, Fasihi-Ramandi M, Namdar N, Abdollahi S, Mousavi S, SamiZadeh B, Allahverdi GH. Surveying the Effect of the Phenol Compounds on Antibacterial Activity of Herbal Extracts: In vitro Assessment of Herbal Extracts in Fasa-Fars Province. Journal of Fasa University of Medical Sciences. 2016;6(2):210220. [Persian]

8.Eid HA, Alshahrani MA, Abo-Alazm EA, Musleh MM, Taha TH, El-Deeb NM. Assessing the Effects of Different Plant Extracts on Primary Dental Plaque Colonizer and Human Fibroblast Cells. Austin J Dent. 2015; 2(3): 1025. Austin J Dent.;2(3-2015)

9.Koech KR, Wachira FN, Ngure RM, Wanyoko JK, Bii CC, Karori SM, et al. Antimicrobial, synergistic and antioxidant activities of tea polyphenols. Microbial Pathogens and Strategies for Combating Them: Science, Technology and Education, Formatex Research Center, Badajoz. 2013:971-81.

10.Subramaniam P, Eswara U, Reddy KM. Effect of different types of tea on Streptococcus mutans: An in vitro study. Indian journal of dental research. 2012;23(1):43.
11.Naderi NJ, Niakan M, Fard MK, Zardi S. Antibacterial activity of Iranian green and black tea on streptococcus mutans: an in vitro study. Journal of Dentistry (Tehran, Iran). 2011;8(2):55. [Persian] 12.Mirpour M, Siahmazgi ZG, Kiasaraie MS. Antibacterial activity of clove, gall nut methanolic and ethanolic extracts on Streptococcus mutans PTCC 1683 and Streptococcus salivarius PTCC 1448. Journal of oral biology and craniofacial research. 2015;5(1):7-10.

13.Borjianbrojeni S, Kaveh baba heydari E, Mortezaei S, Karimian M, Shirzad M, Validi M. The antibacterial effects of the hydroalcoholic extracts of aloevera and glycyrrhizaglabra against cariogenic bacteria in vitro. J Babol Univ Med Sci. 2016;18(4):14-20. [Persian]

14.Bansal S, Choudhary S, Sharma M, Kumar SS, Lohan S, Bhardwaj V, Syan N, Jyoti S. Tea: a native source of antimicrobial agents. Food research international. 2013;53(2):568-84.

15. Melok A, Lee L, Mohamed Yussof S, Chu T. Green Tea Polyphenol Epigallocatechin-3-GallateStearate Inhibits the Growth of Streptococcus mutans: A promising new approach in caries prevention. Dentistry journal. 2018;6(3):38.

16.Sheikhinejad S, Babaeekhou L, Barzin U, Zingiber Officinate an anti-streptococcus mutans herbal drug: which is more suitable? J Res Dent Sci.2017;14(3):162-69.

17.Golmohammadi A. A Comparative Study on Antimicrobial Effect of Iranian Green Tea and Hibiscus Tea on Growth of Oral Cariogenic Bacteria Streptococcus mutans PTCC 1683. Journal of Research in Medical and Dental Science. 2018;6(5):361-4.

18.Barroso H, Ramalhete R, Domingues A, Maci S. Inhibitory activity of a green and black tea blend on Streptococcus mutans. Journal of oral microbiology. 2018;10(1):1481322.

19.Rathinavelu PK, Thangavelu L. Comparison of antibacterial activity of green tea and black tea: An in vitro study. Drug Invention Today. 2019;12(4): 836-8 